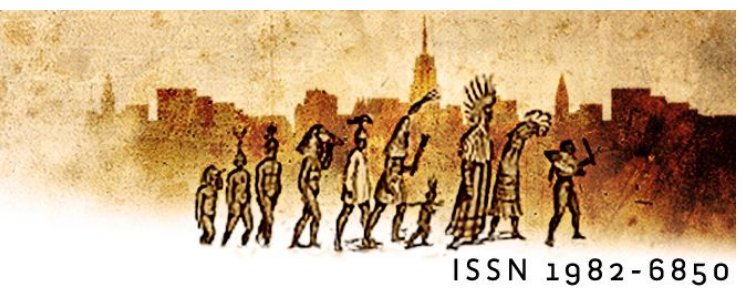

\title{
Sobre a semiótica de Heráclito e o sentido literário da Filosofia
}

Nazareno Eduardo de Almeida (UFSC) ${ }^{\mathrm{i}}$

\begin{abstract}
Resumo: Este artigo possui uma intenção geral que se realiza através de três intenções específicas. A intenção geral é fazer uma contribuição relevante em direção a um tratamento adequado do sentido literário da filosofia a partir da semiótica de Peirce (especificamente do que chamou de retórica formal) cognitivamente orientada. As intenções específicas são: (i) mostrar que as figuras retóricas, deste ponto de vista, quando operadas pelos textos filosóficos, têm um valor argumentativo; (ii) que o sentido literário da filosofia de Heráclito, amplamente reconhecido mas insuficientemente analisado, se deve a uma concepção semiótica do logos, e que a figura retórica fundamental de seus fragmentos é a alegoria entendida enquanto inferência analógica, de modo que o sentido semiótico do pensamento de Heráclito, até agora apenas indicado, possa ser amplamente explicitado; e (iii), por contraste, mostrar a insuficiência da tese segundo a qual "não há o fora do texto" (atualmente tão em voga) e que trivializa a relação entre filosofia e literatura, obstando sua análise adequada, tal como aqui proposta.
\end{abstract}

Palavras-chave: Semiótica; Heráclito; Filosofia; Literatura.

\begin{abstract}
This paper has a general intention accomplished through three specific intentions. The general intention is to make a relevant contribution toward an adequate approach of the literary sense of philosophy from the Peircean semiotics point of view (particularly from what he called formal rhetoric) cognitively oriented. The specific intentions are: (i) to show that rhetoric figures, from this standpoint, when operated by philosophical texts, have an argumentative value; (ii) that the literary sense of Heraclitus' philosophy, widely recognized but not enough explained, is due to a semiotic conception of logos, and that the fundamental rhetoric figure of their fragments is the allegory understood as analogical inference, so that the semiotic sense of Heraclitus thought, until now just pointed out, can be extensively exposed; and (iii), by contrast, to show the insufficiency of the general thesis according to which "there is no outside-text" (presently so fashionable), which trivializes the relation between philosophy and literature, preventing an adequate analysis of that relation, such as here proposed.
\end{abstract}

Key-words: Semiotics; Heraclitus; Philosophy; Literature. 


\section{Da retórica à semiótica: a relação filosofia-literatura a partir da semiótica de Peirce cognitivamente orientada e o caráter peculiar da filosofia de Heráclito}

Pensar sobriamente é a maior virtude, e a sabedoria consiste em dizer a verdade e
agir compreendendo a natureza mesma. Heráclito, aforismo $112 .^{1}$

De um lado, desenvolve-se há algum tempo, dentre as inumeráveis ramificações atuais da filosofia, uma filosofia da literatura. Preocupada com a discussão de teses filosóficas clássicas sobre os diversos aspectos deste polissêmico conceito. ${ }^{2}$ De outro, a partir da linguística cognitiva, da psicologia e da filosofia do sujeito incorporado, vem se desenvolvendo uma poética cognitiva, que faz uma ponte entre os aspectos usualmente tidos como literários (metafóricos e ficcionais) no discurso e o modo como tais funções discursivas operam na vida mental cotidiana. ${ }^{3}$ Falta ainda, porém, uma análise filosófica e empiricamente mais adequada do sentido literário da filosofia. ${ }^{4}$

Tanto no caso da filosofia da literatura quanto no caso da poética cognitiva a relação polissêmica (de aproximação e de diferença) entre filosofia e literatura acaba por ser deixada em segundo plano e, portanto, não é investigada, tendendo a assumir tal relação como dada e mesmo como não problemática. Acredito que um tratamento adequado do sentido literário da filosofia pode contribuir tanto para avanços na filosofia da literatura quanto para o avanço dos estudos da poética cognitiva e, indiretamente, da própria linguística cognitiva e da filosofia do sujeito incorporado.

Mas para além desta necessidade de expansão dos campos de investigação acima mencionados, um tratamento do sentido literário da filosofia é uma tarefa urgente como

\footnotetext{
${ }^{1}$ Este texto é uma versão bastante resumida de um ensaio mais longo em preparação. Por conta disso, o presente artigo conterá várias lacunas (que tentarei minimizar pelo bem da brevidade e da clareza, essas duas virtudes exortadas pelos retóricos antigos). A aparente complexidade do texto se deve à sua ambição múltipla, mas simples: apresentar indicações filosóficas gerais sobre o literário na filosofia a partir de uma semiótica cognitivamente orientada e aplicar este método na análise dos argumentos de Heráclito em favor de sua concepção semiótica da relação mente-mundo, a qual, apesar da distância temporal, parece-me ainda filosoficamente relevante para se falar do literário que pode comparecer nos argumentos filosóficos em geral.

2 Uma coletânea de autores e temas relevantes para a filosofia da literatura encontra-se em HAGBERG/JOST, 2010. Desenvolvi teses não ortodoxas sobre a filosofia da literatura e da arte semioticamente orientadas em ALMEIDA, 2007. O presente texto, em certa medida e com o distanciamento inevitável, procura refletir sobre algo apenas indicado vagamente neste livro sobre o sentido literário da filosofia.

3 Um trabalho pioneiro e ainda relevante no contexto da poética cognitiva encontra-se em GIBBS, 1994.

4 As únicas tentativas que me pareceram relevantes (mas ainda insuficientes) encontram-se, no tocante à relação em geral, em DANTO, 2010, e, no tocante ao mundo pré-socrático, em MOST, 2008.
} 
parte do esforço para superar uma tendência danosa e recente de apagamento da diferença entre filosofia e literatura, tendência ironicamente originada nas "filosofias da diferença", para as quais "não há o fora do texto". Tal tendência de apagamento é particularmente danosa porque trivializa o conceito de literatura e, por isso, torna-se incapaz de oferecer uma análise filosófica e empiricamente adequada tanto da literatura (e de seu enraizamento na vida mental dos seres humanos) quanto, sobremodo, dos aspectos literários operados na filosofia. O resultado, na quase totalidade das vezes, é desastroso e conduz geralmente a mistificações vazias. Feitas essas considerações introdutórias, passemos à análise do tema mesmo.

Com efeito, é um fato amplamente reconhecido que diversos gêneros literários foram inicialmente elaborados ou operados de modo relevante pelos filósofos: o poema, o aforismo, o diálogo, a carta, a confissão, o romance, o ensaio, dentre outros. De modo geral, supõe-se que tal uso seria retórico (metafórico e ficcional) em um sentido por vezes pejorativo do termo: apenas como um modo exterior de apresentação didática de pensamentos que, supostamente, poderiam ser apresentados de modo puramente filosófico (literal e factual).

Penso que tal é um equívoco. As operações ditas retóricas ou literárias são parte intrínseca de muitas filosofias, constituem um aspecto inerente de seu modo de argumentação. Nessas filosofias se apresenta, por antonomásia, o sentido literário da filosofia. Nelas, contudo, não necessariamente se desenvolve uma filosofia da literatura, nem mesmo uma visão do aspecto literário da linguagem em geral. No entanto, tais filosofias são reconhecidas por muitos como filosofias com alto grau literário, aquilo que, de modo abreviado, podemos chamar de filosofias literárias. Platão, Sêneca, Lucrécio, Agostinho, Montaigne, Pascal, Rousseau, Hume, Schopenhaver, Kierkegaard e Nietzsche são alguns exemplos notórios.

No âmbito da filosofia acadêmica comum, de um lado, tende-se a deixar de lado o aspecto literário dessas obras em função de uma apresentação mais "literal" de algum aspecto de seus argumentos, teses e conceitos, posição que tem gerado frutos importantes, embora por vezes parciais, justamente por sua visão mais ou menos simplista do aspecto literário que opera nas argumentações desses filósofos; de outro lado, porém, realizam-se dessas obras análises "filosóficas" ou "literárias" que, enfatizando o lado mais "metafórico", acabam por repetirem a si mesmas ou aos seus arautos, sem chegar a compreender 0 
"ponto" em que a filosofia e a literatura se tornam praticamente indistinguíveis no texto filosófico, o que não significa, de modo algum, que não haja diferenças entre filosofia e literatura, mas que tal relação de "intersecção" é mais difícil de ser pensada filosoficamente do que supõe tal tendência de interpretação dos obras filosóficas marcadamente literárias.

Parece-me que a pedra-de-toque que nos permite entender tanto a relação de aproximação quanto a diferença entre filosofia e literatura é a própria noção geral de argumentação como aquela que permite uma caracterização adequada do indispensável em um discurso filosófico. Não quero dizer, com isso, que no campo da literatura em sentido estrito, no campo dos textos científicos e no discurso comum não haja argumentação. Bem o contrário. Todavia, por um critério negativo, podemos dizer que o discurso literário é assim muitas vezes composto ou recebido porque pode prescindir de qualquer argumentação em sentido estrito, ou seja, de algum tipo de atitude discursiva com pretensão de verdade, embora possa operá-la de diversos modos e a use amiúde. Também no caso do discurso científico, parece-me que a argumentação é diversas vezes dispensável, especialmente quando é sobrepujada pela atividade da explicação, na qual o próprio argumentativo pode se tornar algo exterior, de modo análogo a como o retórico pode ser apenas auxiliar no campo da argumentação filosófica. No caso do discurso cotidiano, parece-me óbvio que muitos atos de fala ou atitudes discursivas prescindem da forma da argumentação. É no caso da filosofia que se torna impossível dispensar algum tipo de atitude argumentativa. Essa atitude argumentativa nos permite identificar, como uma condição necessária (mas talvez não suficiente), aqueles discursos que de algum modo têm para nós valor filosófico, mas não exclui do discurso filosófico também a atividade criativa que caracteriza primariamente o discurso literário nem a explicação que se apresenta como finalidade precípua do discurso científico. ${ }^{5}$

\footnotetext{
5 Do ponto de vista semiótico que adoto, penso que em uma porção considerável dos códigos significantes usados (especialmente os lógico-matemáticos) nas ciências são códigos apenas semidiscursivos ou não discursivos. Em relação a eles, o discurso é ou um meio de acesso e aprendizado inicial de sua operação (como no caso da matemática avançada) ou um meio de exposição didática. Curiosamente, em analogia como o papel usualmente atribuído aos efeitos retóricos em relação ao discurso em geral, o próprio discurso se torna como que um "meio retórico" de exposição de ideias e conceitos altamente abstratos que pertencem à "malha conceitual" operada pelos cientistas desses campos. A precisão desses códigos significantes torna a palavra e muitas vezes a argumentação secundária ou acessória em relação à estrutura abstrata da própria teoria. $\mathrm{Na}$ medida em que essas são avaliadas como verdadeiras também por causa de seu poder explanatório, entendese por que a argumentação pode se tornar prescindível ao nível da explicação, assim como o próprio discurso tal como operado no cotidiano.
} 
Assim, de modo geral,o sentido literário da filosofia se apresenta naqueles textos filosóficos ou filósofos onde as figuras de linguagem operam ou são criadas como esquemas conceituais ("metáforas conceituais" na expressão de Lakoff e Johnson) e não apenas como um meio de exposição propedêutica. Mesmo assim, na medida em que são filosofias, permanece nessa operação intrínseca das chamadas figuras retóricas uma pretensão de verdade, finalidade precípua da atitude argumentativa que caracteriza a filosofia. Em suma: no texto filosófico que se vale de modo criativo das figuras retóricas em seus argumentos, fazendo delas metáforas conceituais de algum tipo, o que chamamos literário coincide com o filosófico, ou seja, o aspecto literário na filosofia é filosófico. ${ }^{6}$

$\mathrm{Na}$ medida em que nos filósofos mais amplamente reconhecidos como literários muitos argumentos são construídos com figuras retóricas, estas se tornam condições de sentido para estes mesmos argumentos enquanto são guiados por alguma concepção com algum tipo de pretensão de verdade. Quando esta concepção se vale dos tropos como componentes indispensáveis de seus argumentos, de sua força persuasiva entendida como algo inerente a eles, podemos dizer que certas concepções filosóficas, em seu método, possuem os traços do estilo literário que comumente atribuímos àqueles que usualmente chamamos de escritores. Mas em lugar de apresentar de modo genérico esta concepção sobre o sentido literário que pode ser encontrado em obras e filósofos, gostaria de apresentá-la in loco, tomando um caso particular do que podemos chamar de filosofia literária. Trata-se de Heráclito. A escolha, porém, não é arbitrária. Heráclito pode ser (e tem sido) reconhecido como o primeiro filósofo literário da história da filosofia ocidental. Antes dele, o sentido literário da filosofia é difuso, ainda não explícito. Mas em Heráclito tal sentido se apresenta claramente, na medida em que, pela prosa, constrói os argumentos para sua concepção filosófica através de poderosas metáforas, como qualquer leitor logo percebe ao reparar na feitura de seus fragmentos. ${ }^{7}$

Do ponto de vista já reconhecido, Heráclito não pode ser "acusado" de se valer dos tropos retóricos ou figuras de linguagem como um expediente "didático", tal como

\footnotetext{
${ }^{6}$ Numa direção análoga vai o interessante livro de Daniel Cohen sobre as formas possíveis de correlação entre argumentos e metáforas no discurso filosófico. Cf. COHEN, 2003. Cohen identifica quatro possíveis formas de relação entre os argumentos filosóficos e as metáforas: (1) as metáforas que usamos para falar sobre argumentos; (2) o papel das metáforas nos argumentos; (3) os modos pelos quais usamos as metáforas como argumentos; e (4) a possibilidade de lermos os argumentos como metáforas. Cf. COHEN, 2003, p. 197 ss.

7 Uma rápida (e a meu ver ainda insuficiente) análise de Heráclito dentro do modelo da linguística cognitiva e da filosofia e psicologia do sujeito incorporado encontra-se em LAKOFF/JOHNSON, 1999, cap. 16.
} 
usualmente se atribui à poesia de Parmênides ou de Empédocles. ${ }^{8}$ E essa impossibilidade se deve a dois fatores: primeiro, porque Heráclito se vale da prosa e não do verso; segundo, porque apresenta uma dura crítica aos poetas então reconhecidos no senso comum grego (Homero, Hesíodo, Arquíloco). Heráclito faz uso consciente dos tropos retóricos (do metafórico e ficcional) como partes próprias de seus argumentos, sem as quais eles não fazem sentido. O mais surpreendente, porém, revelando mais uma faceta de seu gênio, é que tal uso consciente dos tropos acontece quase um século antes que a retórica clássica, constituída a partir da sofística, tenha começado a identificar e analisar o modo de funcionamento desses tropos. São essas as razões imediatas que conferem a Heráclito o posto já reconhecido de primeiro filósofo a operar com instrumentos considerados literários, sobretudo quando encarado a partir da noção de literatura no mundo moderno.

Todavia, aquilo que ainda não é reconhecido e que gostaria de explicitar neste texto é justamente que Heráclito opera com os tropos retóricos como parte de sua argumentação por conta de uma concepção semiótica (filosófica) sobre a relação entre os seres humanos e o mundo através da linguagem. Embora tenhamos algumas indicações breves do papel fundador de Heráclito na história da semiótica ocidental, uma análise que explicite a motivação filosófica desse papel ainda não foi realizada. Penso que tal análise não pode ser feita através dos ecos da análise dos tropos pela tradição da semiologia francesa, a qual desemboca, por sua mecânica conceitual própria, nos já mencionados exageros de uma mitificação do texto em si, mistificação que se condensa no lema "não há fora do texto". Tal tendência "estetizante" condena o tratamento dos tropos retóricos a uma crítica literária travestida de semiologia e, portanto, perde totalmente de vista o valor geral da própria semiótica como teoria filosófica e científica sobre a significação em geral e sobre a significação discursiva.

Antes, o tratamento que farei aqui do modo como Heráclito se vale dos tropos retóricos como argumentos consistirá em uma aplicação e em um desenvolvimento do que Peirce indicou pelo título de retórica formal ou especulativa, a qual, em conjunto com a gramática formal ou especulativa, constitui o todo da semiótica por ele delineada. A título de analogia didática, pode-se dizer que assim como as geometrias não euclidianas acabam

\footnotetext{
8 Tal acusação em relação a Empédocles é exposta por Aristóteles em sua Poética, 1, 1447b 17-20. No caso de Parmênides, a designação de sua obra como poema didático, muito comum entre os helenistas, revela a mesma opinião.
} 
por englobar as euclidianas como parte de seu aparato conceitual, assim também a retórica formal de Peirce engloba a retórica clássica dentro de uma estrutura conceitual fundada filosófica e cientificamente. ${ }^{9}$ Nesse sentido, a proposta de Peirce antecipa em alguns decênios o que atualmente é também chamado de lógica informal ou simplesmente teoria da argumentação. ${ }^{10}$

De modo geral, para Peirce, a retórica formal analisa a força que os argumentos possuem para se tornarem persuasivos e aceitáveis para uma mente qualquer. Essa força é o modo pelo qual os argumentos (de qualquer tipo) se tornam relevantes como apresentação efetiva (pragmática) de uma concepção sobre algo. A retórica formal, portanto, determina o modo como os argumentos de qualquer tipo (científicos, filosóficos, artísticos ou da vida comum) apresentam o sentido e a verdade da concepção que os organiza. A retórica formal de Peirce, como parte essencial de sua semiótica, é uma teoria geral sobre os métodos de argumentação, a qual, como proponho aqui, pode se aplicar também à análise das características que tais métodos adquirem quando operados por determinadas concepções que chamamos mais estritamente de filosóficas.

Conjugada com os desenvolvimentos recentes da linguística cognitiva, da filosofia e da psicologia do sujeito incorporado, bem como da poética cognitiva, a retórica formal de Peirce pode nos oferecer um modo de abordagem que ao se distanciar da crítica literária hiperbólica do "texto pelo texto"(alimentada pela semiologia francesa) nos aproxima de uma visão empiricamente mais adequada do sentido literário encontrado em certas filosofias. Longe da semiótica que desemboca na tese do "texto pelo texto" porque a ela anterior, a semiótica de Peirce se funda justamente em uma convicção cientificamente

\footnotetext{
${ }_{9}^{~ C f . ~ v . ~ g ., ~ P E I R C E, ~ 1960, ~ v . ~ 1, ~ p . ~ 296-98 . ~ N a ̃ o ~ e ́ ~ m i n h a ~ i n t e n c ̧ a ̃ o ~ f a z e r ~ q u a l q u e r ~ e x e g e s e ~ d o s ~ d e t a l h e s ~ d a ~ r e t o ́ r i c a ~}$ formal proposta por Peirce. Interessa-me seu valor operatório como intuição filosófica geral, aqui conjugada com a visão cognitiva do metafórico e ficcional ("literário"). Sobre a retórica formal de Peirce há diversos estudos. Alguns que me parecem mais relevantes são: KEVELSON, 1984; LISZKA, 2000; COLAPIETRO, 2007.

${ }^{10} \mathrm{Um}$ dos mais célebres e abrangentes desenvolvimentos da lógica informal ou teoria da argumentação se encontra justamente naquilo que se chama de 'nova retórica', proposta especialmente por Chaïm Perelman. Com efeito, Perelman e Olbrechts-Tyteca, no Tratado da argumentação: a nova retórica, compreendem os tropos retóricos como parte constitutiva e importante do que chamam de ponto de partida da argumentação. Cf. PERELMAN/OLBRECHTS-TYTECA, 1999, p. 189-208. Uma passagem que mostra a possível aproximação desta teoria com a estrutura conceitual aqui delineada é a seguinte: "Para nós, que nos interessamos menos pela legitimação do modo literário de expressão do que pelas técnicas do discurso persuasivo, parece importante não tanto estudar o problema das figuras em seu conjunto quanto mostrar em que e como o emprego de algumas figuras determinadas se explica pelas necessidades da argumentação. Notemos, a esse respeito, que Cournot já havia reconhecido que as figuras não atuavam somente sobre a sensibilidade. Pois é fácil, escrevia ele, perceber que "a linguagem dos filósofos não é menos figurada do que a dos oradores e dos poetas"' PERELMAN/OLBRECHTS-TYTECA, 1999, p. 190, grifo dos autores.
} 
orientada da relação mente-mundo através dos signos. A retórica formal mostra justamente como essa relação se apresenta nos argumentos como a "força lógica" de persuasão efetivamente empregada na confirmação ou corroboração de uma concepção sobre algo. Neste modelo semiótico, as figuras retóricas - listadas um tanto ao acaso pela retórica clássica e atualmente organizadas e estudadas na estilística e na crítica literária podem ser pensadas não apenas como ornamentos que embelezam o discurso (em especial o literário), mas também, em muitos casos, como formas pelas quais os argumentos se estruturam e permitem compreender o sentido e a possível verdade de uma determinada concepção sobre algo. Aquilo que atualmente é chamado de poética da mente ou mente literária ${ }^{11}$, portanto, pode ganhar em clareza e poder explanatório quando se analisa, na perspectiva formal da retórica proposta por Peirce, como os tropos retóricos tradicionais se apresentam em determinadas concepções filosóficas já reconhecidas como literárias não como seus ornamentos literários dispensáveis (muito menos como a propalada retoricidade universal que trivializa a separação entre filosofia e literatura), mas como parte intrínseca de suas construções conceituais e mentais, ou seja, de suas concepções.

Neste passo, porém, é preciso ter cuidado. Fazer uma análise semiótica de como os tropos retóricos contribuem para a "força lógica" de uma argumentação filosófica não necessariamente significa dizer que em todas as filosofias literárias e suas concepções está em jogo uma concepção semiótica da relação entre mente e mundo através da linguagem. Isso seria novamente recair nas perigosas generalizações apressadas, em especial naquela que trivializa tanto a noção de concepção filosófica quanto, sobretudo, a de concepção semiótica sobre algo. Usar a retórica formal de Peirce (cognitivamente orientada) para conseguir mostrar o caráter semiótico da filosofia de Heráclito é algo específico deste texto. Não se pode dizer, sem mais, que o fato de Pascal, por exemplo, se valer dos tropos retóricos em sua argumentação filosófica torna sua concepção filosófica uma concepção de caráter semiótico. É preciso não confundir o mapa com o território, para usar uma batida metáfora.

Todavia, como quero mostrar, a operação dos tropos como modos de argumentação em Heráclito, na primeira filosofia explicitamente literária da tradição, pode tanto nos ajudar a compreender ("por metonímia") de modo mais geral o valor cognitivo e conceitual

${ }_{11}$ Tenho aqui em mente as concepções complementares apresentadas por Raymond Gibbs em seu já clássico Poetics of mind (GIBBS, 1994) e no livro de Mark Turner intitulado The literary mind (TURNER, 1996). 
desses tropos nas argumentações de todo tipo através do valor cognitivo desses tropos nas concepções filosóficas. Além disso, a aplicação desta concepção semiótica a Heráclito nos permite ver, dentro do quadro da história das ideias, como essa filosofia é animada por uma concepção semiótica da relação entre mente e mundo, razão pela qual se vale dos tropos retóricos antes que eles tenham se cristalizado na sua posição tradicional de "ornamentos" do discurso em geral e, na história recente, compreendidos usualmente como propriedades exclusivas dos discursos comumente tomados como literários ou como algum tipo de "concessão" literária de um discurso não literário.

Muitos conceitos, pelo caráter de brevidade necessário a um artigo, terão de ser operados sem maior esclarecimento ou apenas esclarecidos de passagem, mas espero que isso não comprometa a compreensão do alvo mais geral deste texto: falar de modo não mistificador e não trivial da percepção unânime, mas não devidamente explicada, de uma relação entre filosofia e literatura através da análise da primeira filosofia literária da tradição ocidental. Feitas essas observações gerais sobre o método e sobre as hipóteses aqui propostas, passemos à coisa mesma em questão.

\section{A concepção semiótica de Heráclito do ponto de vista dos seus conceitos: a interpretação do logos do mundo através do logos humano}

Contra certa tendência de encarar Heráclito exclusivamente pela metáfora do profeta e mesmo do poeta inspirado ${ }^{12}$ (exacerbando assim o estereótipo de obscuridade voluntária que a antiguidade lhe conferiu), aquilo que a metáfora conceitual fundamental de Heráclito - expressa na máxima "tudo é um" - nos aponta é justamente a estrutura objetiva do mundo mesmo, em sua dinâmica de processo contínuo (o "rio de Heráclito"), aquilo que tem de ser continuamente investigado através do que se apresenta na percepção, mas sem que nos percamos na multiplicidade sensivel nem nas opiniões parciais dela derivadas. Em um tempo em que o espírito científico ainda era rudimentar, Heráclito mantém sempre três coisas em vista com seu esquema conceitual maior: (i) a estrutura objetiva do mundo (o logos do mundo) é algo que se apresenta em tudo que é dado na percepção, mas que tende

12 Essa tendência aparece moderadamente em CORNFORD, 1989, caps. 7, 9; mas se torna um tanto hiperbólica em GUTHRIE, 1962/85; bem como em COLLI, 2010-13; e também em HÖLSCHER, 1993. Uma visão de Heráclito que acredito ser mais adequada - contendo em si tanto a faceta do profeta e em certa medida do poeta inspirado, mas mostrando que tal faceta é complementar e mesmo subordinada àquela que podemos chamar propriamente de faceta filosófica e científica - se encontra em NIETZSCHE, 1989, caps. 5-8; mas de modo mais completo e adequado é defendida em KAHN, 2009. 
a se ocultar por sua grandeza e complexidade; (ii) e justamente por isso Heráclito critica todas as concepções então existentes a sua volta como simplificações dessa mesma ordem universal em relação à qual ele mesmo se esforça ao máximo para dar testemunho fidedigno, afastando-se da atitude daqueles que são, em suas palavras, "artesãos e testemunhas de mentiras" (DK B 28). ${ }^{13}$ Mas também sempre mantém que (iii) a interpretação desta estrutura é não somente uma tarefa virtualmente infinita (dada a nossa limitação de vida e de intelecto), mas também que esta interpretação é necessária primariamente para que a alma humana (como indivíduo e como espécie) possa conhecer a si mesma.

É a partir destes parâmetros gerais da metáfora conceitual da unidade na totalidade que podemos nos apropriar adequadamente do caráter semiótico da concepção heraclítica do logos. A tendência antes mencionada, que exacerba a imagem do profeta inspirado, vale-se geralmente dos fragmentos 92 e 93 como suposta evidência de que apenas a metáfora oracular perpassaria a fala de Heráclito. Também é por conta desses fragmentos que já foi inicialmente indicado o lugar de Heráclito na tradição da semiótica antiga (cf. ROMEO, 1976; MANETTI, 1993, p. 17-22), tanto por dar importância à instituição antiga dos oráculos (tradição reconhecida como primeira manifestação e reflexão sobre o processo semiótico) quanto por se valer conceitualmente do verbo 'sêmainein' pela primeira vez na história da filosofia.

Ambos os fragmentos são citados por Plutarco em seu Dos oráculos da pitonisa. O primeiro descreve: "A sibila pronuncia-se com boca delirante, sem risos, sem ornatos e sem perfumes, e sua voz ressoa por mil anos por causa do deus que fala nela" (DK B 92). O segundo apresenta como que a conclusão desta descrição: "O senhor, cujo oráculo está em Delfos, não diz <a verdade> (legei) nem <a> oculta (kryptei), mas dá <seu> indício (sêmanei)" (DK B 93).

De modo geral, não se consegue alcançar o sentido semiótico contido nesta metáfora porque sua compreensão usual me parece equivocada. Por conta disso, não se consegue fazer a passagem para o caráter semiótico global que está em jogo tanto na operação

\footnotetext{
13 Heráclito determina a condição de nossos pensamentos sobre a ordem do mundo pela metáfora conceitual do testemunho. Cf. DK B 28, 34, 101a, 107 (55 por afinidade). Uma análise deste tema ultrapassa o presente

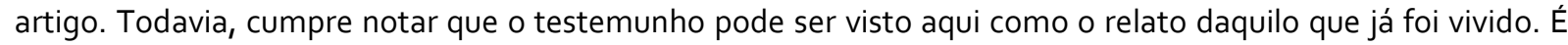
em especial aplicada aos sentidos (esp. olhos e ouvidos) que a metáfora conceitual do testemunho ganha um aspecto manifestamente cognitivo (psicológico e epistêmico). O frag. 107 é revelador aqui: "Más testemunhas para os homens são olhos e ouvidos para os que têm almas bárbaras".
} 
discursiva do próprio Heráclito (o "seu" logos) quanto na suposição de que o próprio mundo possui um logos (estrutura, proporção, medida), o qual é em alguma medida interpretável indiretamente pela mente humana em suas operações com signos (linguísticos ou não). ${ }^{14} \mathrm{~A}$ meu ver, a falha dos intérpretes é a seguinte: tomar a metáfora de Heráclito como se fosse primariamente aplicada a sua própria linguagem. Ora, o que a imagem nos diz não é primariamente o modo como Heráclito concretamente opera seu discurso, mas como o próprio mundo, em seu princípio unificador e ordenador, se pronuncia a nós através dos fenômenos. Como o deus que se apresenta sem nenhum ornamento, de modo seco e direto na palavra da pitonisa, cuja voz apresenta mensagens sempre novamente interpretáveis ("ressoa por mil anos"), assim também o mundo, como manifestação sensível da estrutura divina nele encarnada, se pronuncia a nós e, implicitamente, já está presente na estrutura de sentido que mantém nosso próprio discurso (cf. DK B 72). O sentido e a verdade dessa pronúncia, como o do deus Apolo em Delfos, não estão dados nem ocultos no que é dito, apenas indicados. É certo que em vários aforismos Heráclito se vale de um símile da linguagem oracular, especialmente no que podemos chamar os seus enigmas e fábulas sutis, como mostrarei depois. Contudo, a imagem da sibila e do dito oracular parece-me antes uma imagem do próprio modo como o mundo "fala" a nós através dos fenômenos do que uma imagem universal aplicável a todos aforismos remanescentes de Heráclito.

Isso se evidencia a partir de um outro fato conceitual ainda não compreendido pelos intérpretes: não é apenas ao modelo divinatório que a fala de Heráclito está vinculada, como se pensa usualmente. É possível ver traços originais de uma vinculação de sua fala com outra importante tradição semiótica antiga: a medicina (cf. MANETTI, 1993, cap. 03).15

\footnotetext{
14 Uma anedota contada por Plutarco é aqui reveladora da concepção não necessariamente linguística dos signos por parte de Heráclito: "Aqueles que, sem a voz, por meio de símbolos (symbolikôs), <indicam> as coisas que devem ser pensadas (ha dei fradzontes) não são diferenciadamente louvados e admirados? Como Heráclito, que exortado pelos concidadãos a pronunciar (eipein) uma máxima (gnômen) sobre a concórdia (homonoias), depois de descer da tribuna, tomou uma taça de água fresca e misturou nela farinha de cevada, e, depois de ter mexido a mistura com um ramo de menta, bebeu-a, indicando (endeixamenos) a eles que a cidade se mantém em paz e concórdia se se basta com as coisas que encontra a sua volta (tois tychousin arkeisthai), sem necessitar das coisas luxuosas." (DK A $3 \mathrm{~b}$ ad finem). Um breve comentário filológico-exegético sobre essa passagem encontra-se em MONDOLFO/TARÁN, 2012, p. 65-66.

15 Neste capítulo, Manetti apresenta uma diferença entre o método analógico dos primeiros filósofos jônicos e o método propriamente semiótico iniciado na medicina hipocrática. A diferença, segundo Manetti (que acompanha DILLER, 1932) é que enquanto o modelo analógico procura (re)conhecer uma estrutura unificante e inaparente por comparação com uma multiplicidade aparente, o modelo semiótico da medicina passa do aparente ao inaparente de modo condicional e causal. Assumindo heuristicamente esta divisão, penso que Heráclito está no limiar entre os dois modelos. Ainda está colocado no modelo analógico (como veremos depois em mais detalhe) pela remissão da totalidade das aparências ao esquema da unidade na multiplicidade.
} 
Heráclito fala explicitamente dos médicos (DK B 58), e talvez também por isso a tradição posterior tenha criado as anedotas e as duas cartas apócrifas sobre sua estranha relação com eles. ${ }^{16}$ Embora haja certa ironia e malícia no fragmento (e nas anedotas e cartas), os pensadores da medicina na escola hipocrática estão entre os primeiros a "imitar" suas ideias e seu estilo. Por conta disso, a vinculação de Heráclito com a tradição médica não é retrospectiva, mas prospectiva (e, talvez, por isso, ainda não compreendida). Ou seja, não parece ser Heráclito quem toma da medicina sua visão semiótica sobre a relação mentemundo; antes é a tradição médica então nascente quem toma de Heráclito o princípio fundamental do que será posteriormente a semiótica médica e filosófica na antiguidade. Dentre as várias imitações do pensamento e do estilo de Heráclito constantes no Corpus hippocraticum, a mais longa e que toma mais elementos conceituais e estilísticos do efésio é uma parte inicial do tratado De victu in morbis acutis (Do regime nas doenças crônicas), colocada por Diels e Kranz como a primeira (e sem dúvida mais importante) das imitações do efésio. Em um momento desta imitação, num contexto com ecos inegáveis dos conceitos e do estilo de Heráclito, é mencionada pela primeira vez na tradição da medicina antiga a tese que está na base não apenas do desenvolvimento da semiótica médica, mas também de toda a discussão semiótica sobre os tipos e as estruturas lógico-epistêmicas

Contudo, coloca-se já no segundo modelo quando opera enunciados condicionais contrafactuais, como no caso do fragmento $05,07,09,15,18,23,49,99,107$, mas também implicitamente nos fragmentos 02, 40, 50, 94 e 114. Algo nesse sentido é corroborado em BARNES, 1983. Independentemente deste papel limítrofe de Heráclito, do ponto de vista aqui adotado, tanto o que Manetti indica como modelo analógico quanto o que chama de modelo semiótico iniciado na medicina serão tomados como duas maneiras possíveis de exercício do método semiótico por parte dos filósofos e médicos do período pré-socrático.

${ }^{16}$ Sobre as anedotas, veja-se LAÉRCIO, 2006, IX, 2-4. As cartas apócrifas encontram-se editadas, traduzidas e comentadas em MONDOLFO/TARÁN, 2012, p. 323-333. 
das inferências a partir de signos que será travada entre os estoicos, os epicuristas e os $\operatorname{céticos}^{17}$, a saber: "Os homens <em geral> não têm ciência (ouk epistantai) de como investigar (skeptesthai) as <coisas> que não aparecem (afanea) a partir das que aparecem (ek tôn fanerôn)." (DK C 1, 11, p. 381) $)^{18}$

Ora, além de ressoar o pessimismo epistêmico de Heráclito em relação aos seres humanos, essa frase ecoa diretamente a tese de Heráclito segundo a qual devemos procurar a partir da estrutura aparente (harmoniê fanerês) a estrutura inaparente (harmoniê afanês) nela contida, pois esta domina (kreittôn) a primeira (DK B 54). Tal estrutura inaparente que governa a aparente está na base do famoso aforismo segundo o qual a "natureza ama esconder-se" (DK B123). Esta vinculação mostra de modo claro que Heráclito entende a filosofia em geral (a começar pela sua) como um investigação e intepretação dos signos (ícones, índices e símbolos) da estrutura inaparente que governa a totalidade do que aparece a nós. Essa estrutura é aquilo que, em outro fragmento, o 114, chama de lei divina, aquela em relação à qual é necessário se concentrar, como o que é comum (xynôi) a tudo, para poder "falar com inteligência" (xyn noôi legontas), em um de seus sutis trocadilhos. E isso é necessário justamente porque esta lei governa (kratei) através de todas as coisas e se manifesta de diversos modos. A partir disso, pode-se sair de uma visão ainda muito limitada da concepção semiótica do logos defendida por Heráclito, aquela que se confina à metáfora da linguagem oracular; bem como, saindo desta visão parcial, compreender o real valor das metáforas conceituais apresentadas nos fragmentos 92-93, em especial o valor semiótico do conceito de indicação (sêmainein).

\footnotetext{
${ }_{17}$ Uma acurada análise da semiótica entendida como teoria da inferência a partir de signos em Aristóteles, nos estoicos e nos epicuristas encontra-se em ALLEN, 2001. Sobre a semiótica desenvolvida pelos céticos em conexão com as escolas citadas e com a medicina, veja-se GLIDDEN, 1983. É interessante notar que os primeiros filósofos que mais reivindicaram-se como herdeiros e seguidores de Heráclito foram os estoicos. $\mathrm{O}$ seu desenvolvimento da semiótica, portanto, pode ser entendido como levando adiante indicações filosóficas que eles retiraram de seu mestre pré-socrático.

${ }^{18} \mathrm{~A}$ tendência geral atualmente é datar este escrito como pertencente ao final do século $\mathrm{V}$ e início do século IV a. C., ou seja, composto por um hipocrático que teria vivido cerca de cem anos depois de Heráclito. Tarán, em seu comentário ao trecho, vê um possível influxo da tese atribuída a Anaxágoras por Sexto Empírico (DK B 21): "pois as aparências (fainomena) <apresentam> uma visão (opsis) das coisas não-evidentes (adêlôn)". Independente de tal proposta ser correta, como reconhece Tarán, o autor do tratado utiliza claramente a terminologia do fragmento 54 de Heráclito ('fanerês' versus 'afanês'), mas deixa de chamar a atenção para o fato de não usar a terminologia do fragmento de Anaxágoras. Ademais, na sequência o autor do tratado se vale de diversos pares conceituais manifestamente retirados de Heráclito e não de Anaxágoras. Cf. MONDOLFO/TARÁN, 2012, p. 252-53. Uma breve discussão de toda essa injunção conceitual encontra-se em DILLER, 1932, p. 32-33.
} 
A ligação entre esta visão semiótica mais ampla sobre o conceito de logos pode ser encontrada no uso metafórico que Heráclito faz da audição como escuta e, no fundo, como forma de compreensão e intepretação. O fragmento fundamental aqui é o célebre 50: "não de mim, mas do logos escutando é sábio homologar: tudo é um". O jogo entre 'logos' e 'homologar', para além de um efeito retórico, marca justamente o ato de escutar o próprio logos e não Heráclito, que o diz. Como a pitonisa tem de ser esquecida em função da mensagem que ela apresenta para a interpretação, assim também é preciso escutar aquilo que está indicado no próprio logos que Heráclito nos apresenta. O seu dito enigmático a ser interpretado ("verificado") é: "tudo é um". A escuta interpretativa toma o dito de Heráclito como algo que o transcende, como um pronunciamento (testemunho fiel) de algo a respeito do mundo enquanto origem e destinação do logos humano.

Três fragmentos tomados em conjunto podem nos fazer compreender melhor a metáfora cognitiva e semiótica da escuta. O primeiro é o fragmento 34: "Ouvintes descompassados (axynetoi) que com surdos se parecem; o dito dá deles testemunho: "presentes estão ausentes"". O segundo é o fragmento 72: "Em relação ao logos com o qual constantemente convivem e que controla todas as coisas, eles se diferenciam, e as coisas que encontram todos os dias lhes aparecem estranhas." O alvo dessas irônicas sentenças é o mesmo: aqueles que "não sabendo ouvir, não <sabem> falar" (DK B 19). No primeiro fragmento, com sua forma paradoxal, os humanos em geral são ouvintes descompassados e, por isso, semelhantes a surdos. O termo grego 'axynetoi', vertido por 'descompassados' significa mais diretamente 'os que não compreendem'. A audição da maioria é apenas acústica, não interpretativa daquilo que ouvem. O dito popular então é apropriado por Heráclito: embora corporalmente presentes, sua mente está ausente do mundo em que vivem, como aqueles que dormem se voltam para um mundo particular (cf. DK B 89).

Essa ausência é descrita no segundo fragmento. A maioria se diferencia, se afasta daquilo com que mais convive: o logos. Aqui, o jogo sutil do efésio toma o logos tanto no sentido do discurso, aquilo com que mais convivemos, quanto no sentido do logos do mundo, aquele que controla todas as coisas. A expressão 'que controla' está pelo grego 'dioikounti', o qual significa inicialmente administrar uma casa. A expressão 'todas as coisas', por sua vez, está pelo grego 'ta hola', ou seja, por todas as coisas que possuem a forma de algo completo e articulado, tal como as diversas coisas que compõem, sinergicamente, uma casa. Com isso, Heráclito chama a atenção para um dos lugares mais comuns da vida 
humana: a casa, aquele lugar onde centramos nosso cotidiano. Em suma: por diferirem em relação à sua casa maior, o mundo governado pelo logos e que se insinua a todo tempo no discurso que se pronuncia em suas casas, os seres humanos acabam por perceber as coisas do mundo como estranhas. O tema do sentir-se em casa em toda parte será desenvolvido à exaustão pelos estoicos em seu conceito do humano como cidadão do mundo. Esta estupefação diante do mundo se revela como a ignorância da arte de escutar o logos, tanto aquele que operam diariamente, quanto, por isso, aquele que se apresenta ao longo dos processos que compõem o mundo mesmo. Por conta disso, "não sabendo escutar, não <sabem> falar" sobre o mundo que está a sua volta e que também está dentro de si, atravessando-os no discurso que possibilita a vida humana como tal.

Com Marcovich (cf. MARCOVICH, 2012, p. 59-68), é preciso perceber que em Heráclito o logos (o do próprio Heráclito, mas sobretudo o do mundo) possui quatro aspectos complementares e virtualmente inseparáveis: o aspecto lógico da universalidade que ultrapassa todas as idiossincrasias pessoais de pensamento; o aspecto ontológico (que prefiro chamar henológico) de ser a figura fundamental em que se apresenta a unidade na multiplicidade; o aspecto epistêmico de ser o critério para decidir sobre a verdade dos discursos humanos; bem como o aspecto ético de ser aquilo que permite avaliar quais de nossas máximas de vida (de pensamento e comportamento) estão de acordo com a natureza ou se chocam com ela.

Mas para além de Marcovich, é preciso ver esses quatro aspectos unificados pela concepção semiótica de fundo que anima a construção teórica de Heráclito: ao tomar aquilo com que mais diretamente convivemos, nosso discurso, Heráclito encontra uma grande metáfora conceitual para nos ensinar sobre nossa relação conosco mesmos enquanto indivíduos, sobre nossa relação com os demais indivíduos e grupos humanos, bem como sobre nossa relação com o mundo natural e histórico que habitamos. É por isso que, muito antes de Peirce nos exortar a compreender de modo mais adequado a semiose infinita em que nos encontramos imersos, Heráclito fundamenta uma filosofia que nos aponta para o processo contínuo de pormos o mundo em obra na linguagem tornando a linguagem mundo vivido e vivente na distensão espaço-temporal da alma humana. Nem tanto ao mundo, nem tanto à alma, mas entre elas é que Heráclito constitui, juntamente com seu contemporâneo Parmênides (mas diferentemente dele), a primeira filosofia que põe em 
evidência, através do metafórico e ficcional ("literário") a complexa correlação de pensamento, linguagem e mundo. ${ }^{19}$

\section{A concepção semiótica em ação: a alegoria como tropo fundamental e suas manifestações nos fragmentos}

\subsection{A alegoria: da retórica clássica à semiótica cognitiva}

Há diversos estudos analisando as peculiaridades da linguagem de Heráclito: sua vinculação com a linguagem poético-oracular e profética, e com o nascimento da prosa científica (KAHN, 2009; GUTHRIE, 1962-85; CORNFORD, 1989); sobre sua vinculação com a poesia oral e a ocorrência de certas figuras de linguagem em seus fragmentos (ROBB, 1983); sobre seus padrões argumentativos (FRÄNKEL, 1993); sobre sua vinculação com os temas da retórica nascente (HOFFMANN, 2003, 2006; POSTER, 2006); sobre sua vinculação com a tradição da intepretação alegórica dos oráculos (HÖLSCHER, 1993); sobre os conectivos lógico-sintáticos que contêm a face argumentativa mais visível de seus aforismos (BARNES, 1983). No que segue, valho-me direta ou indiretamente de todos esses estudos, mas minha pretensão aqui é a de usá-los em um contexto conceitual mais filosófico, mas não menos exegético: no contexto da análise do sentido literário da filosofia e como esse sentido é primariamente realizado, de modo "metonímico", por Heráclito em sua concepção semiótica do logos.

Dentro do quadro conceitual mais amplo aqui em jogo, penso que a unidade conceitual e argumentativa da concepção semiótica de Heráclito se apresenta governada, do ponto de vista das figuras retóricas, pela figura chamada desde a antiguidade de alegoria, entendida tanto como uma metafigura quanto como um procedimento argumentativo analógico. A finalidade desta parte do artigo consiste em mostrar como e por que Heráclito opera efetivamente a alegoria enquanto estratégia conceitual e argumentativa de seus aforismos em favor de sua concepção semiótica do logos, e, por isso, da unidade que perpassa a multiplicidade. Para cumprir esta finalidade, é

\footnotetext{
19 Penso que uma concepção semiótica também anima o coração da ontologia parmenídica, mas não é possível falar disso aqui. Note-se apenas que, segundo Parmênides, todas as propriedades intrínsecas do queé ou ente (to eon, em seu dialeto) são os "muitos signos" (polla sêmata) que se deixam entrever no caminho da verdade, propriedades que são alcançadas apenas por meio da redução ao absurdo, procedimento lógico tão importante para toda a argumentação (mas especialmente a filosófica), cujo primeiro registro conservado é justamente o central fragmento 8 de seu poema. Para além de sua ontologia ser uma "tautologia" (um discurso sobre o mesmo), ela pode também ser vista como uma semiologia do ser, uma "leitura lógica" das propriedades intrínsecas (os signos) disso que, segundo o eleata, é sempre o mesmo.
} 
necessário apresentar as figuras retóricas usuais dentro de uma concepção filosoficamente adequada sobre o papel das mesmas no discurso em geral, bem como no discurso filosófico. Tal apresentação sumária permite mostrar o que antes foi dito: que a retórica formal proposta por Peirce, conjugada com a atual visão cognitiva do metafórico e ficcional ("literário"), não descarta a retórica clássica em nome de uma concepção totalmente outra, mas a incorpora dentro de um quadro conceitual mais adequado em relação ao modo como hoje entendemos a relação mente-mundo através da linguagem.

Sobre o que se pode chamar genericamente de figuras retóricas (tropos, figuras de linguagem e figuras de pensamento), cumpre dizer que devem ser entendidas como apontando para três aspectos da operação metafórica e ficcional (literária) do discurso em geral; e, portanto, não como espécies de um gênero de objetos dados (como tende a ser na retórica clássica), pois deste modo se perde o sentido operativo e funcional das figuras retóricas em qualquer dos seus usos na linguagem comum e também na ciência, na literatura e na filosofia. Os tropos, figuras de linguagem e figuras de pensamento apontam para os três aspectos que assume o literário ("retórico") nas operações argumentativas do discurso em geral tendo em vista defender ou atacar uma concepção sobre algo: o aspecto intraproposicional (o metafórico operado ao nível dos termos que compõem os enunciados), o proposicional (o uso metafórico do enunciado como um todo) e o aspecto interproposicional (a operação mais explicitamente argumentativa do metafórico e ficcional ao nível do encadeamento inferencial com vistas a uma conclusão). Ademais, os tropos e figuras identificados pela retórica clássica, tomados na presente perspectiva, podem apresentar um aspecto semântico (de mutação do sentido literal suposto nos termos, nos enunciados e inferências), um aspecto sintático (mutação da estrutura usual dos termos, dos enunciados e das inferências) e um aspecto pragmático (como uma mutação do uso corrente de atos de fala e atitudes argumentativas).

Munidos dessas determinações conceituais de fundo sobre as figuras retóricas, podemos retirar algumas conclusões filosoficamente interessantes sobre a alegoria a partir de como ela se apresenta (com certa vagueza e arbitrariedade voluntárias ${ }^{20}$ ) na súmula da

\footnotetext{
20 Logo no início de seu tratamento dos tropos e figuras de linguagem e de pensamento, Quintiliano relata haver uma grande controvérsia entre gramáticos e filósofos"sobre o gênero, espécies, número e sobre a interdependência" desses expedientes estilísticos, os quais considera ser a "fina flor" da técnica retórica. Diz que não se engajará neste debate porque seu objetivo é mais didático do que teórico (cf. QUINTILIANO, 2003, VIII, 6, 1-4, p. 203). Embora tenha algum fundo de verdade, esta justificativa é mais "retórica" do que real, pois sua organização das figuras retóricas exibe certa pretensão de sistematicidade e exaustividade.
} 
retórica antiga contida nas Instituições oratórias de Quintiliano (séc. I d. C.). Analisada do presente ponto de vista, pode-se dizer que a alegoria não é apresentada por Quintiliano exatamente como uma figura entre outras. Por assim dizer, a alegoria é uma metafigura. $\mathrm{E}$ isso por duas razões.

Em primeiro lugar, por sua própria definição geral, a alegoria é a "metáfora continuada" (QUINTILIANO, 2003, VIII, 6, 14). Isso significa: enquanto a metáfora, como tropo, se apresenta nos diversos tipos de funções conotativas ("uso figurado") que os termos podem assumir dentro de um enunciado, a alegoria (como figura de linguagem e de pensamento) se apresenta nos diversos tipos de funções conotativas ("figurativas") em que um ou vários enunciados, como um todo, podem ter. A alegoria, assim, é o uso metafórico dos enunciados e não apenas de algum de seus termos componentes. Portanto, inicialmente, a alegoria é uma metafigura porque amplia os efeitos metafóricos intraproposicionais dos termos para torná-los efeitos metafóricos proposicionais e interproposicionais, ou seja, efeitos metafóricos dos enunciados e de seu encadeamento argumentativo. Deste modo, como metafigura gerada pela ampliação da metáfora, a alegoria, em suas diversas formas de manifestação, contém virtualmente e acaba por operar todos os efeitos que as várias formas da metáfora podem produzir dentro dos enunciados. Destarte, aquelas funções usualmente reconhecidas sob o nome de metáfora podem ser arregimentadas na operação da alegoria, funções como a sinédoque, a metonímia, o neologismo, a antonomásia, a metalepse, o epíteto, o trocadilho, entre outras. Com efeito, é justamente este caráter interproposicional que permite o uso argumentativo da alegoria.

Em segundo lugar, como já se entrevê no dito acima, a alegoria é uma metafigura também porque esses efeitos metafóricos proposicionais e interproposicionais se apresentam de inúmeros modos: como enigma, comparação, parábola, fábula, paradoxo, máxima, provérbio, paráfrase e como ironia, a qual, por sua vez, se apresenta de diversos modos, como sarcasmo, fineza, eufemismo, simulação, confrontação etc. É preciso acrescentar que todas essas (e outras) possíveis manifestações da alegoria se valem também de efeitos sintáticos das figuras, como a aliteração, a prosopopeia, a assonância, a sindérese, o oximoro, a anáfora, o assíndeto etc. Em todas essas formas possíveis e suas combinações, a alegoria se apresenta de diversos modos conforme a atitude e a finalidade da argumentação. Como metafigura que arregimenta os efeitos metafóricos ao nível dos 
termos, dos enunciados e, sobretudo, dos encadeamentos enunciativos, a alegoria pode se tornar, em alguns casos, um método de argumentação que se vale dos aspectos semânticos, sintáticos e pragmáticos das figuras retóricas em função da defesa de certa concepção sobre algo. Pode-se, portanto, falar de um caráter alegórico geral que assume um enunciado, um argumento ou uma argumentação qualquer, seja ela apresentada implicitamente em um poema, romance ou drama, seja ela apresentada explicitamente na argumentação cotidiana ou, mais cuidadosamente, na argumentação filosófica.

$\mathrm{Na}$ verdade, completando a operação de transposição da alegoria como pensada na retórica clássica e exposta por Quintiliano para o cenário conceitual aqui em jogo, o que está suposto na relação entre metáfora e alegoria exposta na retórica clássica pode ser considerada como um caso particular da relação entre a metáfora e a analogia, tal como entendida pelas ciências cognitivas atuais: como um conjunto de operações lógicas e psicológicas bastante complexo em que podem atuar as metáforas de diversos modos; e não entendida de modo tradicional como uma dentre as figura de linguagem, geralmente a comparação. O conceito de analogia tem uma longa história e tem sido recentemente explorado e aplicado em diversas áreas (psicologia, computação, lógica, linguística, filosofia etc.), especialmente ligado ao conceito de metáfora (entendido em sentido amplo). ${ }^{21}$ Para os presentes propósitos, basta tomarmos uma caracterização bastante geral sobre esse polimórfico procedimento lógico e psicológico: a analogia é o processo de estabelecer correlações estruturais de vários tipos (icônicas, indiciais, simbólicas e mistos dessas) entre objetos ou conjuntos de objetos inicialmente agrupados em categorias lexicais, semânticas ou ontológicas mais ou menos distintas. Essas correlações, porém, são sempre orientadas a um fim e são realizadas tomando um domínio de objetos já conhecido, assumido como fonte (source), para mapear algum aspecto desconhecido ou relevante de outro domínio, assumido como alvo (target). ${ }^{22} \mathrm{Em}$ muitos casos, esta finalidade é mais explicativa ou mesmo expressiva, tendo uma função mais didática do que especulativa. Em outros casos, porém, a analogia é feita de modo criativo, para estabelecer ou ressaltar algum aspecto novo ou relegado de objetos de diferentes domínios considerados em correlação

\footnotetext{
${ }^{21}$ Uma abordagem semiótica da história do conceito de analogia, especialmente na Idade Média, encontra-se em DEELY, 2002. Uma coletânea com contribuições em todos esses campos de estudo da analogia encontrase em HELMAN, 1988.

${ }^{22}$ Essa concepção da operação lógica e psicológica da analogia está baseada em LAKOFF, 1987, cap. 17; JOHNSON, 1987, cap. 5i JOHNSON, 1988; TURNER, 1988.
} 
estrutural. ${ }^{23} \mathrm{Em}$ ambos os casos, diversos tipos e modos de operação da metáfora são requisitados na realização da operação analógica.

Se entendemos a alegoria como um tipo de analogia, como uma forma de transmissão, compreensão, operação, ampliação e criação de esquemas conceituais (metáforas "fortes" e metáforas conceituais), então a análise da alegoria deixa de ser apenas da ordem retórica, estilística ou da crítica literária em sentido tradicional, mas se aplica também e sobremaneira a um procedimento de ordem lógica e psicológica com repercussões ontológicas, uma vez que os esquemas conceituais operados criativamente na alegoria não mais supõem categorias fixas de objetos (como no caso da oposição entre sentido próprio e figurado na retórica), mas supõe uma mobilidade categorial possível e efetivamente operada pelos sujeitos corpórea e culturalmente situados, mobilidade compreensível pela análise adequada da correlação entre nossos processos psicossomáticos, nossos códigos significantes (especialmente o discurso) e estratos gerais do mundo cultural e natural que nos cerca. Para além de um fenômeno "estilístico" e de "ornamento", a alegoria ganha um estatuto cognitivo e semiótico.

Entendida assim, a alegoria ganha o status de procedimento argumentativo que se vale das metáforas para estabelecer algum tipo de analogia entre objetos ou domínios de objetos pertencentes a diferentes categorias lexicais, semânticas e ontológicas. Pensada neste registro, a alegoria como metafigura se apresenta como um conjunto de modos pelos quais é possível realizar inferências analógicas, ou seja, correlações entre domínios de objetos diferentes de modo tanto a esclarecer as propriedades ou aspectos dos objetos de um dos domínios tomado como alvo a partir de um outro tomado como fonte, quanto de estabelecer novas formas de correlação entre os domínios de objetos e, assim, transformar esquemas já existentes ou constituir outros. A oposição (em vários aspectos vaga e imprecisa) entre o sentido próprio (literal) e sentido metafórico (figurado) da retórica clássica e da filosofia da linguagem tradicional é agora transposta para o par fonte-alvo da

\footnotetext{
${ }^{23}$ Do ponto de vista lógico, pode-se dizer que essas correlações entre estruturas de domínios distintos podem ser isomórficas ou não isomórficas. Quando são isomórficas, em princípio, as metáforas que servem para estabelecer a correlação podem ter uma paráfrase literal. O mesmo não acontece nos casos de não isomorfismo. Cf. STEINHART, 2001, p. 20; 209-226. Para além de qualquer valoração subjetiva, ambos os tipos lógicos de analogia têm virtudes próprias, mas aquele tipo com o qual lidamos aqui é o tipo de analogia não isomórfica, no qual não há como se fazer paráfrases literais das metáforas sem perder aspectos cognitiva e linguisticamente importantes das mesmas. No caso específico da argumentação filosófica, o uso de analogias não isomórficas pode se dar justamente por meio do uso das figuras retóricas e, dentre elas, principalmente da metáfora e da alegoria.
} 
teoria recente sobre a analogia. ${ }^{24}$ Deste ponto de vista, a alegoria recebe o aspecto de um procedimento cognitivo (lógico e epistêmico) e ontológico pelo qual realizamos a relação mente-mundo através da linguagem. ${ }^{25}$

$\mathrm{Na}$ realidade, este papel cognitivo da alegoria, entendida como procedimento analógico, está implícito em um segundo sentido assumido pela alegoria desde o mundo grego, mas sobretudo no mundo medieval. Trata-se da visão da alegoria entendida não apenas como procedimento puramente linguístico, mas entendida também como um método de interpretação. Esse procedimento foi aplicado na Antiguidade especialmente para apresentar um suposto sentido próprio para a poesia e na Idade Média como princípio hermenêutico de interpretação das escrituras e do mundo entendido como primeira escritura divina, tendo prosseguido de diversos modos na literatura e na filosofia moderna. ${ }^{26}$ Desconsiderando os detalhes, a alegoria como procedimento interpretativo (chamada de alegoria hermenêutica) procura justamente estabelecer correlações entre domínios de objetos distintos tendo um deles como primário e bem conhecido (tomado como fonte) e o outro domínio tomado como alvo, como aquele que tem de ser esclarecido ou conhecido. O procedimento no campo linguístico é aqui colocado a serviço do procedimento a nível psicológico e, sobremodo, ontológico. ${ }^{27}$

\footnotetext{
24 Uma interessante e importante constatação empírica da polissemia das noções de literal e figurado se apresenta em GIBBS, 1994, cap. 2.

${ }^{25}$ Não é possivel discutir aqui essa "mobilidade categorial" indicada pelos trabalhos da linguística cognitiva. De meu ponto de vista, tal mobilidade ainda tem de ser filosoficamente melhor pensada como um argumento em favor de uma concepção que chamo de 'pluralismo ontológico', concepção que exclui tanto o relativismo ontológico, que fere todas as boas intuições ontológicas clássicas, e o fundacionalismo ontológico, que supõe um quadro fixo e imutável de categorias básicas pretensamente apreensível de modo definitivo por alguma ontologia fundamental, seja ela filosófica ou científica. Sobre a visão intermediária entre o "objetivismo" e o "relativismo" em questões de categorização, veja-se LAKOFF, 1987, esp. $2^{\text {a }}$ parte.

${ }^{26} \mathrm{Um}$ tratamento extensivo de diversos aspectos da alegoria hermenêutica desde o mundo grego até recentemente encontra-se em WHITMAN, 2003. Um tratamento da alegoria (retórica e hermenêutica) em paralelo com a metáfora na tradição clássica pagã e cristã greco-romana encontra-se em BOYS-STONE, 2003.

27 Uma visão geral deste tipo de alegoria se encontra em HANSEN, 2006, caps. 1 e 3. Todavia, é preciso mencionar brevemente que não concordo com a visão de Hansen sobre a restrição da alegoria hermenêutica ao contexto medieval (o que Hansen, sem confessá-lo, retira de Benjamin). A descoberta recente do papiro de Deverni, datado provavelmente do século IV a. C., mostra claramente que o uso interpretativo da alegoria já estava presente no mundo grego clássico. É interessante notar, ademais, que este papiro contém a mais antiga citação de dois fragmentos de Heráclito (4 e 94), um tanto misturados, mas claramente compatíveis em sentido com versões usuais retiradas de outros autores. Do ponto de vista documental, esta é uma das evidências para corroborar as minhas análises da alegoria em Heráclito. Não é possível discutir aqui esse papiro e o papel de Heráclito em sua estrutura alegórica de interpretação de um poema órfico. Uma edição, tradução e comentário do papiro, incluindo um capítulo discutindo a presença de Heráclito no mesmo encontra-se em BEGERTH, 2004, esp. cap. 9.
} 
Embora este sentido heurístico da alegoria não seja incompatível com o sentido ainda meramente linguístico, a alegoria hermenêutica coloca em correlação não apenas domínios de sentido (próprio e figurado) dos termos e enunciados, mas também os domínios de objetos referidos ou supostos pelos mesmos. Em termos mais diretos: atrás do uso hermenêutico da alegoria, difundido a partir do século I d. C. (mas já presente na Grécia do séc. IV a. C.), encontra-se em germe, ainda vaga, a alegoria como um procedimento não apenas retórico, mas como um processo psicológico de compreensão dos próprios objetos que são postos em correlação nas analogias, processo que adquire também valor ontológico porque torna-se capaz de operar, transformar e estabelecer novas categorias cognitivamente relevantes de objetos perceptíveis ou pensáveis. É a esse processo criativo de intepretação dos objetos por meio de suas relações estruturais que está em jogo na alegoria hermenêutica, também chamada pela palavra-valise alegorese (que une 'alegoria' e 'exegese'). Em suma, esse uso interpretativo da alegoria mostra-se como primeiro indício do que atualmente entendemos como o valor cognitivo (e ontológico) que as analogias podem ter no processo de compreensão e de investigação dos objetos do mundo e dos modos como nosso pensamento opera tal processo. ${ }^{28}$ Como veremos, as alegorias de Heráclito também têm esta função hermenêutica, uma vez que se propõe a interpretar os diversos modos como se dá a unidade na multiplicidade, em especial como essa unidade pode se apresentar pela correlação analógica.

\subsection{Um panorama sinóptico das formas da alegoria hermenêutica como inferência analógica nos fragmentos de Heráclito}

Feitas essas considerações gerais sobre o sentido analógico do discurso alegórico, tanto do ponto de vista lógico-linguístico quanto psicológico e ontológico, encerrarei este texto apresentando, sinopticamente, as formas em que tal procedimento se apresenta nos fragmentos de Heráclito.

\footnotetext{
${ }^{28} \mathrm{Em}$ certo sentido, a obra filosófica mais importante que faz um uso hiperbólico da alegoria neste sentido são as Enéadas de Plotino, em especial em sua constante referência anafórica (mais ou menos explícita) ao Uno inefável. Todavia, uma exposição dos aspectos alegóricos de Plotino está muito além do escopo deste breve artigo. Diga-se apenas que as alegorias filosóficas de Plotino foram um modelo conceitual de uma parte considerável da filosofia medieval, em especial aquela ligada à teologia negativa e "mística", onde se executa, sobremaneira na Idade Média, a alegorese das Escrituras (a Torah, a Bíblia e o Corão) em sua relação com o mundo e com a condição humana.
} 
De modo geral, o procedimento analógico das metáforas e alegorias do efésio consiste na operação de correlação estrutural, que pode ser proporcional (isomórfica) ou desproporcional (não isomórfica). ${ }^{29}$ Essa operação pode ser apresentada esquematicamente de dois modos. O primeiro é o seguinte:

\section{A está para $B$ segundo a relação $R^{n}$, assim como $B$ está para $C$ na relação $R^{n}$.}

O segundo modo pelo qual se pode apresentar a operação analógica é este:

\section{A está para $B$ segundo a relação $R^{n}$, assim como $C$ está para $D$ na relação $R^{n}$.}

Apresentarei apenas duas observações gerais sobre tais estruturas. Em primeiro lugar, a relação ' $\mathrm{R}^{\mathrm{n} \prime}$ não precisa ser exatamente a mesma nas duas partes da analogia. É isso que permite entender que não apenas os itens (descrições, indicações ou "imagens") que substituem as letras ' $A$ ', 'B' e 'C' podem variar e ser postos em correlação analógica, mas também as relações podem variar e ser postas em analogia. Assim, pode-se pensar que, por exemplo, $A$ está para $B$ na relação $R^{1}$, assim como $B$ está para $C$ na relação $R^{2}$, ou ainda: A está para $B$ na relação $R^{1}$, assim como $C$ está para $D$ na relação $R^{2}$. $A$ analogia não põe apenas "coisas" em correlação estrutural, mas também as próprias relações.

Em segundo lugar, tal correlação é necessariamente transitiva, mas não necessariamente reflexiva e simétrica. Esta última observação é fundamental para entendermos que é apenas a correlação transitiva que é necessária tanto em $\left(R^{n}(A-B):: R^{n}\right.$ $(B-C))$ quanto em $\left(\left(R^{n}(A-B):: R^{n}(C-D)\right)\right.$. Nada impede que a relação entre os termos de cada parte da analogia, bem como a própria relação analógica seja reflexiva e/ou simétrica, mas tal não é indispensável e, sobretudo, são aquelas analogias que não são reflexivas e/ou simétricas que podem ser consideradas as mais criativas e especulativas, em especial nos

\footnotetext{
29 Este esquema conceitual aparece mais explicitamente nos seguintes fragmentos (onde os fragmentos entre parênteses são aqueles onde a estrutura se apresenta mais ou menos implícita): 1, 4, 5, 7, 9,13, 15, 29, 40, 44, $(45), 48,49,52,53,54,(55), 58,62,67,67 a,(68),(70),(75),(76),(78), 79,(88), 89,90,101 a, 102,(107), 111,114$, (117), 134. Tal esquema já foi inicialmente (mas a meu ver insuficientemente) reconhecido em FRÄNKEL, 1993. Uma apresentação da estrutura lógica da analogia próxima daquela aqui explicitada encontra-se em HESSE, 1960. A distinção entre analogias proporcionais (isomórficas) e desproporcionais (não isomórficas) é necessária para compreendermos que as analogias não são simples comparações por semelhança, mas também são procedimentos lógicos e psicológicos que estabelecem diferenças e assimetrias entre objetos e seus domínios.
} 
casos do segundo tipo de analogia, em que não há um termo comum entre ambas as partes, a relação de transitividade é mais complexa do que no caso em que há uma termo comum a ambas. Tais são as analogias mais ousadas que se pode fazer por meio das formas alegóricas, constituindo aquilo que se chama mais usualmente alegoria ou mesmo parábola e fábula. O exemplo da alegoria da caverna de Platão é um caso clássico deste tipo de correlação mais especulativa e mais complexa, mas veremos um caso também em Heráclito. ${ }^{30}$

Feitos esses apontamentos sumários sobre a correlação estrutural em jogo nas analogias do discurso alegórico em geral, passemos a alguns exemplos nos fragmentos. $\mathrm{O}$ fragmento 79 apresenta um exemplo do primeiro modo de operação da analogia. Eis uma tradução (expositiva mais do que literal) do texto: "A relação do homem adulto para com o divino é a de uma escuta infantil, assim como a relação da criança com o homem adulto". Portanto, o homem adulto está na relação $\mathrm{R}^{1}$ com o divino, assim como a criança está na relação $\mathrm{R}^{1}$ com o homem adulto. A relação aqui é claramente transitiva, mas nem reflexiva nem simétrica.

Um exemplo do segundo tipo de analogia alegórica é encontrado no fragmento 90: "Por fogo se trocam todas coisas e todas as coisas por fogo, assim como por ouro os bens (chrêmata) e os bens por ouro". Primeiramente, há quatro termos aqui, postos em correlação: 'fogo/todas as coisas' e 'ouro/bens'. Notamos aqui que a relação analógica, em suas partes componentes, é simétrica e reflexiva, além de transitiva em seu todo. Todavia, a relação que aparece em ambas as partes não é exatamente a mesma, mas é tomada metafórica e metonimicamente, ou seja, todas as coisas estão em uma relação $\mathrm{R}^{1}$ com o fogo (e o fogo na mesma relação com todas as coisas), assim como os bens estão na relação $\mathrm{R}^{2}$ com o ouro (e o ouro com os bens). O uso do mesmo termo, 'trocar', em ambas as partes da analogia não nos deve induzir ao erro de pensar que Heráclito pensa a troca entre bens e ouro e a 'troca' de todas as coisas por fogo e de fogo por todas as coisas como sendo o mesmo tipo de relação. Vemos aqui que não apenas a relação entre quatro termos diferentes é colocada em evidência, mas a própria relação sofre uma transposição metafórica e metonímica. Como sabemos por outros fragmentos e doxografias, para o

\footnotetext{
${ }^{30}$ Uma análise que converge para a visão aqui apresentada sobre a alegoria em sentido estrito como um tipo de analogia com múltiplas interpretações possíveis (exemplificada pela alegoria da caverna de Platão) encontra-se em SHELLEY, 2003, esp. cap. 5.
} 
efésio o fogo é a forma material como a unidade se apresenta na multiplicidade das coisas. Aqui, esta forma unificadora é comparada às relações de troca por meio do ouro como padrão valorativo. Trata-se, portanto, de uma imagem pela qual podemos compreender como todas as coisas são, segundo a complexa analogia posta em obra no importante fragmento 31, "tropos" do fogo (puros tropai), os quais mantêm sempre a mesma proporção (logos) em suas transformações.

Passemos agora a outras manifestações do discurso alegórico. De modo mais específico e por vezes apenas indireto, o mecanismo da correlação analógica se apresenta na forma das máximas e da ironia ${ }^{31}$, bem como na forma dos paradoxos e contradições ${ }^{32}$, as quais, em sua forma extrema, se apresentam como enigmas e fábulas ou parábolas. ${ }^{33} \mathrm{Na}$ realidade, estas formas do discurso alegórico, quase todas já atribuídas diretamente a ele por Quintiliano, são mais propriamente modos do discurso alegórico que podem se apresentar simultaneamente em diversos fragmentos, ou seja, um fragmento que exibe a forma de uma máxima pode também ser um tipo de ironia e enigma. No que segue apenas apresentarei exemplos de cada um desses modos, sem discuti-los detalhadamente.

No que se refere às máximas (gnomai) e à ironia, tais modos do discurso alegórico em Heráclito se correspondem em uma singular codependência: as máximas justificam as ironias e estas corroboram a necessidade de pensar e acatar as máximas. Na realidade, podemos pensar as máximas e as ironias como consequências retiradas a partir de alegorias analógicas tomadas como premissas veladas. Embora nem sempre, muitas das máximas de Heráclito aparecem na forma do discurso imperativo. Um exemplo é o célebre fragmento 35, onde temos a primeira possível ocorrência textual do termo 'filósofo': "é bem necessário que de muitas coisas sejam inquiridores (historas) os homens amantes-do-sábio (filosofous)". Traduzi o termo 'filosofous' por 'amantes-do-sábio' porque o conceito de coisa-sábia (to sofon) é um conceito fundamental com o qual o efésio denota o modo de ser da unidade que atravessa a multiplicidade. Com efeito, a forma da máxima é em Heráclito uma apropriação

${ }^{31}$ Os fragmentos em que mais diretamente se apresenta a forma da máxima são: 02, 18, 35, 41, 44, 45, 47, 49, $50,71,73,78,80,91,95,101,110,112,114,116$. Os fragmentos onde se apresenta de modo mais ou menos direto a ironia são: $04,05,09,14,15,17,19,20,22,29,34,40,42,43,49,51,56,57,58,70,72,73,74,79,82-83$, $87,96,104,107,108,117,121,124,125$.

${ }^{32}$ Os fragmentos onde aparecem paradoxos são: (8), (10), 12, 17, 18, 34, 51, 72, 82-83, 91, 111. Os fragmentos onde se apresenta de modo mais evidente a contradição são os seguintes: 23, 26, 32, 36, 48, 49a, 58, 59, 60, 61, $62,65,67,84,88,103,126$.

$33 \mathrm{O}$ enigma se apresenta mais diretamente nos seguintes fragmentos: $1,14,15,16,21,25,(27), 32,34,43,45$, $51,54,61,75,93,102,124$. As fábulas se apresentam nos fragmentos: $5,15,56,57,58,67 a$. 
de uma antiga tradição dos provérbios e dos ditos célebres atribuídos àqueles que os gregos chamavam de sete sábios, embora os nomes que preenchem este número variem. Heráclito, por sua concepção semiótica segundo a qual sempre novamente temos de interpretar os signos do logos do mundo, não permite que se aplique propriamente aos humanos o nome de sábios. Na concepção de Heráclito, os melhores dentre os seres humanos são apenas amantes-do-que-é-sábio, ou seja, aqueles que se esforçam para interpretar as várias facetas do princípio unificador da totalidade. Neste ponto, percebemos que a máxima, para Heráclito, é a forma pela qual se expressam os imperativos filosóficos maiores, os quais apenas repetem o sentido imperativo do próprio princípio de tudo, como nos revela o fragmento 41: "Uma única é a coisa sábia: ter ciência do imperativo (gnomên) que dirige tudo através de tudo". A expressão inicial 'uma única é a coisa sábia', pelo engenho de Heráclito, tanto fala da única coisa sábia aos seres humanos quanto fala da única coisa sábia: o imperativo único que dirige (kibernêsai) a totalidade.

Ora, a partir deste fragmento podemos perceber aqui a mútua injunção entre as máximas e as ironias, nas diversas formas identificadas por Quintiliano: sarcasmo, eufemismo, fineza, simulação etc. Se tomamos em atenção a máxima expressa no fragmento 41 como a consequência imediata da ironia do fragmento anterior. Com efeito, é assim que Diógenes de Laércio cita ambos os fragmentos, como se corroborando mutuamente. Eis o fragmento 40: "Ter muitas informações (polimathiê) não <necessariamente> ensina <a ter> inteligência, pois senão teria ensinado Hesíodo e Pitágoras, assim como Xenófanes e Hecateu". Nessa ironia há um desfile de célebres antecessores de Heráclito, os quais eram tidos pelo senso comum ou pelas pessoas mais cultas de seu tempo como sábios. Heráclito reconhece que eles possuem muitas informações, são polímatas; mas isso não os torna inteligentes, ou seja, capazes de apreender a ordem da totalidade. A comparação é irônica e prepara a máxima que foi mencionada, na qual se apresenta a própria origem das máximas que devem ser levadas a sério: o imperativo (gnomên) divino, que dirige o mundo, ou seja, tudo através de tudo.

Dados esses exemplos das máximas e da ironia, passemos aos casos do paradoxo e da contradição. De certo modo, os paradoxos estão para as ironias assim como as contradições para as máximas, de modo que vários paradoxos se apresentam também como ironias e várias contradições como máximas. Mas temos de entender o paradoxo aqui em sentido amplo, como aquilo que se choca com alguma opinião comumente aceita. No caso da 
contradição, temos de entendê-la em sentido igualmente amplo, como a colocação de coisas de categorias consideradas incompatíveis em correlação analógica. Na realidade, o fragmento 40 acima citado tem a forma de um paradoxo assim como de uma ironia, pois o senso comum (grego ainda o nosso) entende muitas vezes como sinônimos a inteligência e o ter muitas informações (polimatia). A distinção apresentada por Heráclito soa algo paradoxal para a opinião comum. Outro exemplo de paradoxo é o já antes analisado fragmento 34: "Ouvintes descompassados (axynetoi) que com surdos se parecem; o dito dá deles testemunho: "presentes estão ausentes"". Ele soa paradoxal justamente porque mesmo ouvindo, os seres humanos não compreendem a estrutura de seu próprio logos porque não escutam aquilo que ela supõe: o logos do mundo. O ditado é ele mesmo um paradoxo e revela também a estrutura de uma contradição.

Sobre a contradição, para Heráclito ela apresenta a conhecida tese da unidade dos opostos. Mas para além dessa exposição, ela mostra que, levada ao seu extremo, a alegoria analógica flerta como o oximoro e com o sem-sentido do ponto de vista cotidiano. É certo que a temerária acusação aristotélica indireta segundo a qual, para Heráclito, todas as coisas seriam contraditórias, não se sustenta (cf. Metafísica IV, 3-5). Mas em todo caso, parece certo que Heráclito coloca em dúvida a validade universal do princípio de não contradição advogada por Aristóteles e pela tradição lógica e metafísica que o segue. Embora essa questão não possa ser discutida aqui, cumpre dizer que a contradição representa em Heráclito o limite mesmo da mente humana em seu (possível) esforço de interpretação da estrutura inaparente e unificadora da totalidade. Do ponto de vista das partes isoladas da totalidade, a contradição nunca se apresenta; porém do ponto de vista do todo, delimitado e unificado pelos pares de contrários, estes aparecem como dependentes um do outro tanto para serem quanto para serem compreendidos. Um aforismo que exibe de modo evidente esta oposição entre a visão do todo e a visão apenas da parte é o fragmento 61: "O mar: a mais pura e a mais impura água; de um lado, para os peixes potável e vivificante; de outro, para os humanos, não potável e mortal."

Um aristotélico se apressaria a dizer que a água do mar não porta simultaneamente propriedades contraditórias, mas apenas parece portá-las porque essas propriedades se apresentam em relações diferentes, com peixes e com humanos. No entanto, tal observação só desmente a contradição exposta por Heráclito se supomos que essas propriedades contrárias são propriedades secundárias da água marinha, as quais não 
comparecem na definição de sua essência. Contudo, do ponto de vista da metafísica de Heráclito, onde não há essências, mas processos estruturados, a contradição se mantém intacta: o mesmo princípio unificador que se apresenta sempre de diferentes perspectivas, este princípio que, no limite, unifica as propriedades contrárias no todo do processo. Mas sobre isso não é possível nos determos aqui.

Passemos ao último par de modos do discurso alegórico de Heráclito: o enigma e a fábula. Para manter a brevidade, tomemos um fragmento onde ambos os modos se apresentam amalgamados, o aforismo 56:

Os humanos em sua busca pelo conhecimento das coisas visíveis estão em situação análoga à de Homero, que se tornou o mais sábio para os gregos; pois aquele foi enganado pelas crianças matando piolhos, que lhe diziam: "O que vemos e apanhamos, deixamos, o que não vemos nem pegamos, trazemos conosco".

Como um todo, a analogia alegórica se apresenta na forma da fábula ou parábola. Os seres humanos em geral, em sua relação com o conhecimento do visível, encontram-se na mesma situação que Homero, considerado por esses mesmos seres humanos (no mundo grego) como o mais sábio, a saber: a situação de serem enganados pelo enigma proposto pelos meninos que catavam piolhos. Percebemos que a analogia se apresenta na segunda forma antes descrita $\left(\left(R^{n}(A-B):: R^{n}(C-D)\right)\right.$, ou seja, os seres humanos $(A)$ estão na relação $R^{1}$ com o conhecimento do mundo visível $(B)$, assim como Homero $(C)$ está na relação $\mathrm{R}^{1}$ com o enigma proposto pelos meninos que catavam piolhos (D). Ademais, a analogia exibe a forma de uma metonímia (passagem da parte para o todo): assim como aquele que foi considerado o mais sábio para os gregos foi enganado pelos meninos, assim também os seres humanos se enganam em sua pretensão de conhecer o mundo visível. O enigma proposto pelos meninos, porém, se revela sem uma solução única, diferentemente dos enigmas comuns que conhecemos pelo nome de charadas. $E$ isso porque ele exibe algo paradoxal e até contraditório.

Na realidade, a própria formulação de Heráclito é enigmática (revelando seu gênio literário e filosófico), pois os termos que inicialmente traduzimos por 'vemos' e 'pegamos' são, na realidade, polissêmicos. O termo usado para 'vemos' é 'eidomen', o qual, já antes da época de Heráclito, já em Homero, significava também 'saber' (eidenai). E tal como quando se aproximam os termos 'eidos' e 'genos', o primeiro deixa de ser tradutível por 'forma' e 
tem de ser traduzido por 'espécie', assim também o termo para 'pegamos', 'elabomen', quando secundado diretamente por 'saber' tem de ser traduzido por 'compreendemos'. Assim apreendido, o enigma das crianças nos diz: "aquilo que sabemos e compreendemos é o que deixamos, o que não sabemos e não compreendemos é o que trazemos conosco". Ora, tal é desconcertante, pois supomos usualmente que o que sabemos e compreendemos é o que trazemos e o que não sabemos e não compreendemos é o que deixamos de lado. Compreendido a partir de outros fragmentos de Heráclito, o enigma pode ser interpretado como indicando que nosso conhecimento das coisas visíveis é ainda insuficiente se não compreendemos que a estrutura do visível é dominada pela do invisível (cf. DK B 54). Mas também pode indicar que o desconhecido é aquilo que, como os piolhos não apanhados, está mais próximo de nossa mente. De todo modo, o enigma permanece, convidando-nos a pensar sobre nossa relação em geral com o visível (perceptível), sempre lembrando que nossa melhor sabedoria ainda pode estar enganada em relação a ele.

$$
* * * * * *
$$

\section{Conclusão}

É célebre o pensamento de Montaigne segundo o qual é duvidoso que homens tão inteligentes quanto Pitágoras, Platão e Epicuro realmente acreditassem no que pensavam: eles eram inteligentes demais para tanto; eles encontraram hipóteses razoáveis e as desenvolveram até onde Ihes foi possível. Acredito que deveríamos incluir Heráclito (entre outros) na lista de Montaigne. Dentre outras possibilidades, podemos entender o texto de Heráclito como nos apontando não apenas para a concepção particular de Heráclito, porém principalmente para o seu sentido: esse sentido que nos compele a manter o olhar vigilante na atitude da investigação, da "espera pelo inesperado" (cf. DK B 18). Antes de Sócrates e dos céticos, Heráclito nos exorta a continuar investigando, a decifrar os signos (fenômenos) a nossa volta, para encontrar-lhes o sentido (o logos), desconfiando de toda "sabedoria" instituída. Antes da teoria da verdade como coerência dos hegelianos do século XIX e da teoria holística da significação proposta por Quine, Heráclito postula que a verdade em sentido absoluto só pode ser o todo em sua unidade e que os conceitos, especialmente na correlação de antonímia (dos contrários), só podem ser compreendidos em sua mútua relação e com os domínios da experiência aos quais remetem. Antes que Lukasiewicz 
pontificasse e profetizasse o advento de lógicas não aristotélicas e que, nesta esteira, especialmente Newton da Costa formulasse sistemas formais paraconsistentes nos quais a validade do princípio de não contradição é restrita em infinitos graus possíveis, Heráclito nos aponta para um mundo onde a contradição (real ou aparente, não importa) é algo com o qual nosso pensamento e nossa linguagem têm de lidar constantemente como seu próprio limite. Por fim, antes de Peirce ter proposto uma filosofia falibilista e a noção de semiose ilimitada, Heráclito nos exorta a realizar, com sobriedade e autonomia, a atividade infinita de pensarmos o mundo em relação à nossa própria alma, esta estranha "coisa" com o mais profundo logos porque expande este mesmo logos para torná-lo homólogo com o logos do mundo, de modo a poder entender a si mesma, em uma correlação semiótica ilimitada de si para com o mundo e vice-versa (cf. DK B 45, 115, 50, 101). Assim, o texto de Heráclito perde seu sentido quando é pensado apenas como "texto metafórico e literário", pois o texto literário de Heráclito é filosófico, ou seja, nos diz para não escutar ao texto de Heráclito senão como meio para chegar a pensar sempre novamente o mundo e a posição da mente que pensa esse mesmo mundo. As poderosas e originais metáforas e alegorias conceituais e argumentativas do texto de Heráclito nos convidam a deixá-lo, nos convidam sempre a pensar um pouco melhor, sobretudo.

\section{Referências}

ALLEN, J. Inference from signs: ancient debates about the nature of evidence. Oxford: Clarendon, 2001.

ALMEIDA, N. E. Insignuações: ensaios sobre filosofia da arte e da literatura. Florianópolis: Oficinas de Arte/Bernúncia, 2007.

BARNES, J. "Aphorism and argument". In ROBB, K. (ed.) Language and thought in early Greek philosophy. La Salle: Monist Library of Philosophy, 1983, p. 91-109.

BEGETH, G. The Deverni papyrus: cosmology, theology and interpretation. Cambridge: Cambridge UP, 2004.

BOYS-STONES, G. R. (ed.)Metaphor, allegory and the classical tradition. Oxford: Oxford UP, 2003. 
COHEN, D. Arguments and metaphors in philosophy. Lanham: University Press of America, 2003.

COLAPIETRO, V. "C. S. Peirce's rhetorical turn". Transactions of C. S. Peirce Society, vol. 43, n. 1, 2007, p. 16-52.

COLLI, G. A sabedoria grega, 3 vols; trad. Renato Ambrosio. São Paulo: Paulus, 2010-2013.

CORNFORD, F. Principium sapientiae: as origens do pensamento filosófico grego; trad. Maria M. R. dos Santos. Lisboa: Calouste Gulbenkian, 1989.

DANTO, A. "Philosophy as/of literature". In HAGBERG, G. L., JOST, W. (eds.) A companion the philosophy of literature. Malden/Oxford: Blackwell, 2010, p. 52-57.

DEELY, J. "The absence of analogy". Review of Metaphysics, vol. 55, n. 3, 2002, p. 521-550.

DIELS, H.; KRANZ, W. I presocratici; trad. Giovanni Reale et alii. Milão: Bompiani, 2012.

DILLER, H. "Opsis adêlonta fainomena". Hermes, vol. 67, n. 1, 1932, p. 14-42.

FRÄNKEL, H. "A thought pattern in Heraclitus". In MOURELATOS, A. (ed.) The pre-socratics: a collection of critical essays. Princeton: Princeton UP, 1993, p. 214-228.

GIBBS, R. The poetics of mind. Cambridge: Cambridge UP, 1994.

GLIDDEN, D. "Skeptic semiotics", Phronesis, vol. 28, n. 3, 1983, p. 213-255.

GUTHRIE, W. K. C. A history of Greek philosophy, vol. 1. Cambridge: Cambridge UP, $1962 / 1985$.

HAGBERG, G. L., JOST, W. (eds.) A companion the philosophy of literature. Malden/Oxford: Blackwell, 2010.

HANSEN, J. A. Alegoria, construção e interpretação da metáfora. São Paulo/Campinas: Hedra/Unicamp, 2006.

HELMAN, D. H. (ed.) Analogical reasoning. Dordrecht: Springer, 1988.

HESSE, M. B. "On defining analogy". Proceedings of Aristotelian Society, vol. 60, 1960, p. 79100.

HOFFMANN, D. C. "Logos as composition". Rhetoric Society Quarterly, vol. 33, n. 1, 2003, p. 27-47.

. "Structural logos in Heraclitus and the sophists". Advances in the history of rhetorics, vol. 9, n. 1, 2006, p. 1-32.

HÖLSCHER, U. "Paradox, simile, and gnomic utterance in Heraclitus". In MOURELATOS, A. (ed.) The pre-socratics: a collection of critical essays. Princeton: Princeton UP, 1993, p. 229238. 
JOHNSON, M. The body in the mind. Londres/Chicago: Chicago UP, 1987.

. "Some constraints on embodied analogical understanding". In HELMAN, D. H. (ed.) Analogical reasoning. Dordrecht: Springer, 1988, p. 25-40.

KAHN, C. A arte e o pensamento de Heráclito; trad. Elson V. Filho. São Paulo: Paulus, 2009.

KEVELSON, R. "C. S. Peirce's speculative rhetoric". Philosophy \& Rhetoric, vol. 17, n. 1, 1984, p. 16-29.

LAKOFF, G.; JOHNSON, M. Metaphors we live by. Londres/Chicago: Chicago UP, 1980.

LAKOFF, G.; JOHNSON, M. Philosophy in the flesh: the embodied mind and its challenge to Western thought. Nova lorque: Basic Books, 1999.

LAKOFF, G. Women, fire, and dangerous things. Londres/Chicago: Chicago UP, 1987.

LISZKA, J. J. "Peirce's new rhetoric". Transactions of C. S. Peirce Society, vol. 36, n. 4, 2000, p. 439-476.

MANETTI, G. Theory of signs in classical antiquity; trad. Christine Richards. Bloomington: Indiana UP, 1993.

MARCOVICH, M. Eraclito, frammenti; trad. Piero Inocennti. Milão: Bompiani, 2012.

MONDOLFO, R.; TARÁN, L. Eraclito, testimonianze e imitazioni. Milão: Bompiani, 2012.

MOST, G. "A poética da filosofia grega em seus primórdios?". In LONG, A. A. (org.) Primórdios da filosofia grega; trad. Paulo Ferreira. Aparecida/São Paulo: Ideias \& Letras, 2008.

NIETZSCHE, F. A filosofia na época trágica dos gregos; trad. Maria I. M. de Andrade. Lisboa: Edições 70, 1989.

PEIRCE, C. S. Collected papers, 8 vols. Cambridge: Harvard UP, 1960.

PERELMAN, C.; OLBRECHTS-TYTECA, L. Tratado da argumentação; trad. Maria E. Galvão. São Paulo: Martins Fontes, 1999.

POSTER, C. "The task of the bow: Heraclitus' rhetorical critique of epic language". Philosophy and Rhetorics, vol. 39, n. 1, 2006, p. 1-21.

QUINTILIANO, M. F. L'Instituizione oratoria, 2 vols.; trad. Rino Faranda, Piero Pecchiura. Turim: UTET, 2003.

ROBB, K. (ed.) Language and thought in early Greek philosophy. La Salle: Monist Library of Philosophy, 1983.

. "Preliterate Ages and the linguistic art of Heraclitus". In ROBB, K. (ed.) Language and thought in early Greek philosophy. La Salle: Monist Library of Philosophy, 1983, p. 153206. 
ROMEO, L. "Heraclitus and the foundations of semiotics". Versus, vol. 15, n. 1, 1976, p. 73-90.

SHELLEY, C. Multiple analogies in science and philosophy. Amsterdam/Filadélfia: John Benjamins, 2003.

STEINHART, E. C. The logic of metaphor: analogous parts of possible worlds. Dordrecht: Springer, 2001.

TURNER, M. "Categories and analogies". In HELMAN, D. H. Analogical reasoning. Dordrecht: Springer, 1988, p. 03-24.

. The literary mind. Nova lorque/Oxford: Oxford UP, 1996.

WHITMAN, J. (ed.) Interpretation and allegory: Antiquity to Modern period. Boston/Leiden: Brill, 2003.

\footnotetext{
i Nazareno Eduardo DE ALMEIDA, professor Adjunto no Departamento de Filosofia da Universidade Federal de Santa Catarina (UFSC) e no Programa de Pós-graduação em Filosofia da mesma instituição. Tem como foco principal de suas pesquisas a investigação de aspectos centrais da relação pensamento-linguagem-mundo de um ponto de vista semiótico, tanto a partir de sua história (especialmente em instauração na filosofia antiga ena filosofia contemporânea) quanto de um ponto de vista conceitual e analítico. E-mail: <nazarenoeduardo@gmail.com>.
} 